\title{
A novel role of the natriuretic peptide/cGMP/cGKI pathway in melanoma cells
}

\author{
Sandeep Dhayade ${ }^{1 *}$, Susanne Feil ${ }^{1}$, Christoph Griessinger ${ }^{2}$, Manfred Kneilling ${ }^{3}$, Birgit Schittek ${ }^{3}$, Robert Feil ${ }^{1}$ \\ From 6th International Conference on cGMP: Generators, Effectors and Therapeutic Implications \\ Erfurt, Germany. 28-30 June 2013
}

\section{Background}

The cGMP/cGMP-dependent protein kinase type I (cGKI) signaling pathway is activated by nitric oxide (NO), natriuretic peptides (ANP, BNP \& CNP), and cGMP-elevating drugs. It regulates important physiological functions such as platelet aggregation, smooth muscle tonus, and cell growth and survival. Recent reports indicate that cGMP might also play a role in tumorigenesis. In the present study we found that cGKI is expressed in melanoma cells of murine and human origin.

\section{Results}

Treatment of intact mouse B16 melanoma cells with the membrane-permeable cGMP analog 8-Br-cGMP induced phosphorylation of the cGKI substrates, vasodilator-stimulated phosphoprotein and phosphodiesterase 5. ANP and $\mathrm{CNP}$, ligands of the membrane-bound guanylyl cyclase GC-A and GC-B, respectively, activated the endogenous cGMP/cGKI pathway. CNP-induced cGMP signals were detected in cell extracts by ELISA and in living cells by a FRET-based cGMP sensor [1]. DEA/NO, which stimulates NO-sensitive soluble guanylyl cyclase, did not increase cGMP signaling in B16 cells. Interestingly, activation of cGMP/cGKI signal transduction was associated with an increase in ERK1/2 and p38 phosphorylation, growth and migration of B16 melanoma cells. Similar results were obtained with WM1205 human melanoma cells.

\section{Conclusion}

We have identified a natriuretic peptide/cGMP/cGKI pathway in melanoma cells, which stimulates tumor cell growth and migration in vitro. Pharmacologic inhibition

\footnotetext{
* Correspondence: sandeep.dhayade@uni-tuebingen.de

${ }^{1}$ Interfakultäres Institut für Biochemie, University of Tübingen, Tübingen, Germany

Full list of author information is available at the end of the article
}

of cGMP signaling may offer a promising strategy for the treatment of melanoma.

\section{Authors' details}

'Interfakultäres Institut für Biochemie, University of Tübingen, Tübingen, Germany. ${ }^{2}$ Department of Preclinical Imaging and Radiopharmacy, Laboratory for Preclinical Imaging and Imaging Technology of the Werner Siemens-Foundation, University of Tübingen, Tübingen, Germany.

${ }^{3}$ Department of Dermatology, University of Tübingen, Tübingen, Germany.

Published: 29 August 2013

Reference

1. Russwurm M, Mullershausen F, Friebe A, Jager R, Russwurm C, Koesling D: Design of fluorescence resonance energy transfer (FRET)-based CGMP indicators: a systematic approach. Biochem J 2007, 407:69-77.

doi:10.1186/2050-6511-14-S1-P19

Cite this article as: Dhayade et al:: A novel role of the natriuretic peptide/cGMP/CGKI pathway in melanoma cells. BMC Pharmacology and Toxicology 2013 14(Suppl 1):P19.
Submit your next manuscript to BioMed Central and take full advantage of:

- Convenient online submission

- Thorough peer review

- No space constraints or color figure charges

- Immediate publication on acceptance

- Inclusion in PubMed, CAS, Scopus and Google Scholar

- Research which is freely available for redistribution
() Biomed Central

\section{Biomed Central}

